\title{
PENGARUH KOMPETENSI SUMBER DAYA MANUSIA DAN TEKNOLOGI INFORMASI TERHADAP PENERAPAN AKUNTANSI BERBASIS AKRUAL PADA PENGELOLAAN BARANG MILIK NEGARA
}

\author{
Intan Puspitarini ${ }^{1}$, Amrie Firmansyah ${ }^{2}$, Dian Handayani ${ }^{3}$ \\ ${ }^{1,2,3)}$ Politeknik Keuangan Negara STAN, Indonesia \\ intan.puspitarini@pknstan.ac.id \\ amrie.firmansyah@gmail.com \\ dihandayani@gmail.com
}

\begin{abstract}
This research is aimed to examine the association of human resources'competencies and information technology on the implementation of government accrual based accounting on the state assets management. As mandated by Government Regulation No. 71 of 2010 concerning Government Accounting Standard, the Government of the Republic of Indonesia should prepare its financial reports based on accrual accounting by 2015. This study examines the practice of implementation of accrual accounting in the management and administration of state asset. The examination conducted in this study is different from previous studies which gave more highlight on the preparation and the implementation of accrual accounting in general, while this study gives more focus on one specific object in accrual accounting, that is state assets. This study conducts survey by using questionnaires which are then distributed to units in line ministries and government that responsible in managing state assets. 250 questionnaires were distributed to 16 line ministries and 3 government institutions, 234 of those were successfully returned. From the questionnaires returned, 188 are considered valid. The result ot the study shows that the competence of human resources is associated with the application of accrual accounting on government assets. While, the information technology has different result, it is not associated with the application of accrual accounting on government assets.
\end{abstract}

Keywords: accrual accounting, government assets

\begin{abstract}
Abstrak
Penelitian ini bertujuan untuk menguji pengaruh kompetensi sumber daya manusia (SDM) dan teknologi informasi terhadap penerapan akuntansi Pemerintah berbasis akrual pada Pengelolaan Barang Milik Negara (BMN). Penerapan akuntansi berbasis akrual harus dilakukan oleh Pemerintah mulai tahun 2015 sebagaimana Peraturan Pemerintah Nomor 71 tahun 2010 tentang Standar Akuntansi Pemerintahan. Penelitian ini menguji praktek pelaksanaan akuntansi berbasis akrual dalam pengelolaan dan penataan BMN. Pengujian yang dilakukan dalam penelitian ini berbeda dengan penelitian sebelumnya yang menyoroti persiapan pelaksanaan akuntansi berbasis akrual dan bukan dengan menggunakan objek BMN. Penelitian ini menerapkan survei dengan menggunakan kuesioner. Kuesioner disebarkan kepada Kuasa Pengguna Barang dan Pengguna Barang sebanyak 250 kuesioner di 16 Kementerian dan 3 Lembaga Pemerintah. Jumlah kuesioner yang berhasil dikembalikan dari responden sebanyak 234, sedangkan yang terisi penuh dan dinyatakan valid sebanyak 188 . Dari hasil pengujian hipotesis diketahui bahwa kompetensi sumber daya manusia berpengaruh terhadap penerapan akuntansi berbasis akrual pada penatausahaan BMN. Sementara itu, teknologi informasi tidak berpengaruh terhadap penerapan akuntansi berbasis akrual pada pengelolaan BMN.

Kata kunci : akuntansi berbasis akrual, barang milik negara
\end{abstract}




\section{Pendahuluan}

Reformasi keuangan negara Republik Indonesia (RI) yang dimulai sejak tahun 2003 bertujuan untuk menata kembali struktur dan pengelolaan keuangan negara. Melalui reformasi keuangan negara tersebut, Pemerintah RI berkomitmen untuk memperbaiki kualitas informasi keuangan Pemerintah, baik dari sisi aset, hutang maupun investasi Pemerintah. Serangkaian peraturan diterbitkan sebagai landasan hukum dalam pelaksanaan reformasi tersebut, yang selanjutnya lebih dikenal sebagai 3 (tiga) paket perundangan Keuangan Negara, yaitu Undang-undang nomor 17 tahun 2003 tentang Keuangan Negara, Undang-undang Nomor 1 tahun 2004 tentang Perbendaharaan Negara, dan Undang-undang nomor 15 Tahun 2004 tentang Pemeriksaan atas Pengelolaan dan Pertanggungjawaban Keuangan Negara. 3 (tiga) paket perundangan tersebut mengamanatkan Pemerintah, baik Pusat maupun Daerah, menerapkan akuntansi berbasis akrual secara penuh. Amanat tersebut selanjutnya dijabarkan lebih lanjut dalam Peraturan Pemerintah Nomor 71 tahun 2010, yang menegaskan bahwa akuntansi Pemerintah berbasis akrual harus diterapkan paling lambat 5 (lima) tahun setelah peraturan diundangkan, yaitu pada tahun 2015 .

Penerapan akuntansi pemerintah berbasis akrual membawa beberapa perubahan mendasar dalam tata kelola keuangan negara. Dalam kaitannya dengan BMN, baik berupa persediaan maupun aset tetap, penerapan akuntansi berbasis akrual membawa dampak pada perlakuan, mulai dari tahapan pengakuan sampai dengan pelaporannya. Persiapan penerapan akuntansi Pemerintah berbasis akrual dilakukan Pemerintah secara bertahap. Pada periode 2010-2012, Pemerintah masih menerapkan akuntansi Pemerintah berbasis kas. Dengan basis ini, nilai BMN berupa aset tetap masih disajikan sebesar nilai perolehan dan belum dilakukan penyusutan. Selanjutnya, periode 2013-2014, Pemerintah menerapkan akuntansi Pemerintah berbasis Cash Towards Accrual. Dengan basis ini, Pemerintah sudah mulai menerapkan penyusutan atas asset tetap dan menyajikannya dengan nilai buku, yaitu nilai perolehan atas asset tetap ditambah dengan kapitalisasi yang timbul atas aset tersebut dikurangi dengan penyusutan. Namun demikian, segala bentuk pengeluaran atas aset (contoh pemakaian persediaan, pemeliharaan) belum diakui sebagai beban dalam Laporan Keuangan Pemerintah Pusat. Pada periode ini, Laporan Operasional sebagai bentuk pelaporan Income Statement belum terbentuk. Terakhir, pada tahun 2015, Pemerintah mulai menerapkan akuntansi Pemerintah berbasis akrual penuh. Disini selain penyusutan dan amortisasi aset tak berwujud telah dilakukan, segala bentuk pengeluaran atas aset telah diperhitungkan dan dicatat sebagai beban. Laporan Operasional telah terbentuk, sehingga pos-pos pendapatan yang timbul atas suatu aset juga telah diakui dan disajikan secara memadai.

Berikut perkembangan nilai BMN selama tahun 2007 s.d. 2015:

Tabel

1.1

Perkembangan Nilai BMN

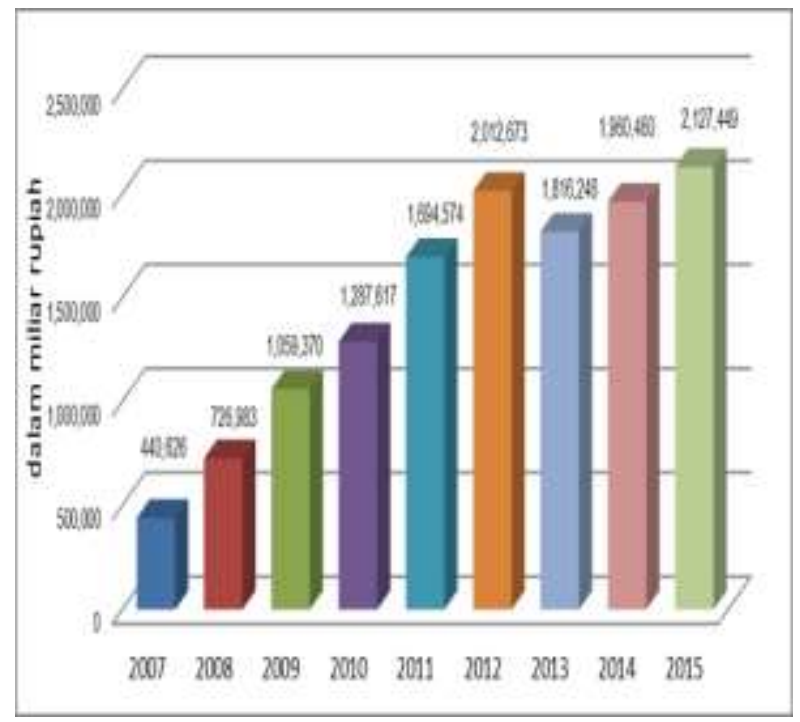

Sumber : Kementerian Keuangan

Perkembangan Nilai BMN tahun 2007 s.d. 2015 tersebut di atas menunjukkan bahwa Pemerintah Pusat telah menginvestasikan ribuan triliun rupiah dalam bentuk Persediaan dan Aset Tetap. UndangUndang Nomor 17 Tahun 2003 tentang Keuangan Negara menetapkan bahwa Menteri Keuangan sebagai pembantu Presiden dalam bidang Keuangan Negara bertindak sebagai Chief Financial Officer (CFO) Pemerintah Republik Indonesia yang 
berwenang dan bertanggungjawab atas pengelolaan aset dan kewajiban negara secara nasional. Hal ini selanjutnya diatur lebih lanjut dalam Peraturan Pemerintah Nomor 27 tahun 2014 tentang Pengelolaan Barang Milik Negara/Daerah yang mengatur bahwa penyelenggaraan pemerintahan negara dan pemerintahan daerah yang efektif dan efisien sangat membutuhkan tersedianya sarana dan prasarana yang memadai yang terkelola dengan baik dan efisien. Aset-aset Pemerintah secara langsung mempunyai peran yang sangat penting dalam pelaksanaan tugas dan fungsi Pemerintah Pusat, yaitu untuk pelayanan masyarakat. Fungsi aset dalam pelaksanaan pelayanan kepada masyarakat sangat bervariasi, mulai dari penyediaan infrastruktur bagi masyarakat (jalan, irigasi dan jaringan), penyokong kebutuhan pangan masyarakat (sarana dan prasarana pertanian, perkebunan, perikanan, dan peternakan), penyediaan fasilitas rumah dan tempat tinggal bagi masyarakat dengan kriteria tertentu, fasilitas kesehatan, pendidikan, penjagaan perbatasan wilayah negara, pertahanan dan keamanan negara, hingga sarana dan prasarana dalam penyelenggaraan diplomasi dan komunikasi Pemerintah..

The International Monetary Fund (IMF) melalui Transition to Accrual Accounting (Khan \& Mayes, 2009) mengungkapkan beberapa nilai positif penerapan akuntansi Pemerintah berbasis akrual, yaitu meningkatkan transparansi, mendorong perencanaan keuangan yang lebih baik untuk memastikan bahwa Pemerintah mampu memenuhi kewajibannya pada saat jatuh tempo, menentukan biaya yang timbul pada satu kegiatan Pemerintah secara sistematis, dan mampu mengukur aset dan hutang yang relevan dengan kebijakan fiskal dan kesinambungan fiskal. Selain fakta adanya kelebihan penerapan akuntansi Pemerintah berbasis akrual, riset yang dilakukan oleh Asian Development Bank menyimpulkan bahwa penerapan akuntansi pemerintah berbasis akrual di negara-negara berkembang harus direncanakan secara realistis dan praktis sesuai dengan kemampuan sumber daya dan kapasitas yang tersedia (Athukorala, 2003). Beberapa faktor yang dapat mendukung keberhasilan penerapan akuntansi pemerintah berbasis akrual adalah strategi implementasi yang direncanakan dengan baik, komitmen, tujuan yang dikomunikasikan secara jelas, sumber daya manusia yang andal, dan sistem informasi yang sesuai dengan kebutuhan (Khan \& Mayes, 2009).

Di Indonesia, penelitian terkait dengan penerapan akuntansi berbasis akrual belum menyentuh aset Pemerintah atau yang biasa disebut dengan Barang

Milik Negara. Putra dan Ariyanto (2015) menguji kualitas SDM, komunikasi, komitmen organisasi, dan gaya kepemimpinan terhadap penerapan standar akuntansi pemerintahan berbasis akrual. Keempat variabel independen tersebut berpengaruh terhadap penerapan akuntansi berbasis akrual. Penerapan akuntansi berbasis akrual dalam penelitian ini hanya sebatas kesiapan Pemerintah Daerah menghadapi penerapan akuntansi berbasis akrual yang diberlakukan tahun 2015. Sementara itu Azman (2015) menyoroti komitmen organisasi, kesiapan SDM, Infrastruktur serta Sistem Informasi Dalam

Menerapkan Standar Akuntansi Berbasis Akrual. Penelitian tersebut menggunakan pendekatan kualitatif deskriptif. Sama halnya dengan Putra dan Ariyanto (2015), Azman (2015) menggunakan pendekatan persiapan pelaksanaan akuntansi berbasis akrual dalam penelitiannya. Dari hasil penelitian Azman (2015) diketahui bahwa Satuan Kerja Perangkat Daerah (SKPD) berkomitmen untuk mengimplementasikan standar akuntansi pemerintahan berbasis akrual pada tahun 2015. Kendala yang terjadi adalah input data atu transaksi ke dalam sistem informasi belum dilakukan sesuai dengan prosedur akuntansi. Permasalahan

lainnya adalah sistem informasi yang ada dapat dikatakan belum siap untuk mendukung penerapan sistem akuntansi pemerintahan berbasis akrual karena sistem informasi yang digunakan berbeda dengan sistem informasi yang digunakan sebelumnya, sehingga pengguna mengalami kesulitan dalam penggunaannya.

Selanjutnya, Kusuma dan Fuad (2013) membuktikan bahwa teknologi informasi tidak berpengaruh terhadap penerapan akuntansi akrual pada pemerintah, sementara Rosiana, Made, dan Yogivaria (2016) membuktikan bahwa teknologi informasi berpengaruh negatif terhadap penerapan akuntansi 
berbasis akrual. Perbedaan tersebut dimungkinkan bahwa data yang digunakan oleh Kusuma dan Fuad (2013) adalah data pemerintah pusat sedangkan Rosiana et al. (2016) menggunakan data pemerintah daerah. Selanjutnya, Kusuma dan Fuad (2013) membuktikan bahwa pelatihan staf mendorong terjadiya peningkatan penerapan akuntansi berbasis akrual dan Rosiana et al. (2016) menemukan bahwa semakin tinggi kualitas SDM maka semakin meningkat penerapan akuntansi berbasis akrual.

Dari pengujian yang sudah dilakukan dalam penelitian sebelumnya, penerapan sistem akuntansi pemerintahan berbasis akrual lebih menekankan kepada persiapan akuntansi berbasis akrual yang dimulai tahun 2015, sedangkan untuk penerapannya itu sendiri itu masih belum dilakukan pengujiannya. Dalam penelitian ini, penerapan akuntansi berbasis akrual lebih menekankan terhadap penerapan yang sudah dilakukan di tahun 2015 dan tahun 2016 untuk instansi Pemerintah Pusat. Adapun penerapan akuntansi berbasis akrual dalam penelitian ini lebih menyoroti BMN karena BMN memiliki dampak signifikan dalam penerapan akuntansi berbasis akrual di Pemerintah Pusat khususnya dalam penyajian di neraca terkait dengan pengukuran dan penilaian BMN. Penelitian ini menguji kualitas SDM dan teknologi informasi karena Penulis beranggapan bahwa berhasil dan tidaknya penerapan suatu ketentuan yang baru dalam hal ini penerapan akuntansi berbasis akrual khususnya untuk BMN terjadi karena kualitas SDM yang mengelola dan menatausahakan BMN tersebut. Sementara itu, teknologi informasi sangat berperan dalam membantu SDM pengelola BMN dalam meningkatkan kualitas informasi BMN.

\section{Kerangka Teori dan Pengembangan Hipotesis Teori Agensi}

Teori ini menjelaskan adanya hubungan kontraktual antara dua pihak atau lebih yang salah satu pihak disebut prinsipal (principal) yang mempekerjakan pihak lain yang disebut agen (agent) untuk melakukan beberapa jasa atas nama prinsipal yang meliputi pendelegasian wewenang (Jensen \& Meckling, 1976). Teori Agensi berupaya menjawab dua masalah yang timbul dalam hubungan antar Prinsipal dan Agen. Masalah pertama yang ingin dijawab yaitu konflik yang terjadi antara Prinsipal dan Agen dalam pencapaian tujuan serta apakah sepadan upaya yang dilakukan Prinsipal untuk mengetahui bahwa yang dilakukan oleh Agen sejalan dengan tujuan Prinsipal. Masalah kedua yang ingin dijawab oleh teori ini adalah pembagian risiko yang muncul ketika Prinsipal dan Agen berbeda dalam menyikapi risiko yang timbul dalam upaya pencapaian tujuan.

Dalam perkembangannya, sebagaimana diungkapkan oleh Jensen (1983), Teori Agensi terbagi dalam dua pendekatan, yaitu positivist dan principalagent. Riset-riset positivist memfokuskan pada pengidentifikasian situasi-situasi yang menimbulkan konflik kepentingan antara Prinsipal dan Agen, untuk selanjutnya dapat disusun tata kelola yang dapat mengatasi perilaku Agen (Eisenhardt, 1989).

Asumsi dasar yang melandasi positivist adalah keyakinan bahwa setiap pihak akan melakukan tindakan yang rasional. Dengan demikian riset positivist meyakini bahwa perilaku oportunis menjadi alasan pemilihan metode akuntasi yang diterapkan. Hubungan agensi muncul ketika Prinsipal mendelegasikan pengambilan keputusan kepada agen. Pendekatan positivist percaya bahwa masing-masing pihak, baik Prinsipal maupun Agen akan mengambil tindakan berdasarkan pada kepentingan masingmasing pihak, dimana tidak sepenuhnya serupa (Gaffikin, 2007).

Berbagi informasi diyakini dapat mengurangi masalah agensi. Oscar \& Gustafsson (2014) melakukan pengujian terhadap fungsi komunikasi informasi untuk mengurangi kendala yang timbul dalam hubungan antar agen mengenai perlakuan akuntansi pendapatan yang ditangguhkan (deferred revenues) pada real estate yang dimiliki pemerintah daerah di Swedia. Ruang lingkup penelitian menempatkan city management office sebagai Prinsipal dan salah satu entitas real estate di kota Bostadsbolaget yang dimiliki pemerintah daerah sebagai Agen. Pemerintah daerah seharusnya melakukan pengelolaan real estate di bawah penguasaannya secara komersial. Sebagaimana dikutip 
oleh Berndtsson and Gustafsson (2014), Bedford \& Baladouni (1962) mengungkapkan bahwa fungsi akuntansi sebagai proses komunikasi dapat berperan sebagai penyedia informasi yang lebih transparan. Hasil studi menunjukkan bahwa saluran komunikasi yang terdiri dari grup informasi, saluran intranet, dan sistem pelaporan internal bermanfaat untuk mengurangi kompleksitas pencatatan pendapatan yang ditangguhkan serta akun-akun lainnya yang mengandung permasalahan agensi serupa.

Pentingnya informasi juga diungkapkan dalam penelitian yang dilakukan oleh $\mathrm{Hu}$, Percy, dan Yao (2015). Revaluasi aset yang dilakukan oleh manager merefleksikan masalah keagenan yang lebih rendah karena motivasi utama manager dalam melakukan revaluasi aset adalah untuk memberikan sinyal mengenai kewajaran nilai aset kepada pengguna laporan keuangan. Revaluasi aset juga mengurangi asimetri informasi antara manager dengan pemilik perusahaan (Hu et al., 2015). Dalam kaitannya dengen penelitian ini, teori agensi menyororoti penerapan akuntansi dalam pencatatan BMN dengan memberikan informasi yang akuntabel dan transparan kepada publik.

\section{Penelitian Terdahulu dan Pengembangan Hipotesis}

Penelitian yang dilakukan oleh Azman (2015), Putra dan Ariyanto (2015), Kusuma dan Fuad (2013), Rosiana et al. (2016) menempatkan kualitas SDM dalam penerapan akuntansi berbasis akrual. SDM memiliki peranan penting dalam kerbehasilan pelaksanaan akuntansi pemerintah berbasis akrual. Begitu halnya dengan pengelolaan dan penatausahaan BMN yang dilakukan dengan basis akrual mengingat sebelum tahun 2015, aturan akuntansi terhadap BMN menggunakan aturan yang berbeda. Dengan demikian, diperlukan SDM yang kompeten atas pengelolaan dan penatausahaan BMN sesuai dengan standar akuntansi pemerinta dalam masa transisi tersebut. Penggunaaan standar akuntansi pemerintah baru untuk pengelolaan BMN membutuhkan kompetensi SDM yang baik melalui pemahaman atas standar akuntansi pemerintah maupun melalui strategi pelatihan kepada pengguna
BMN maupun kuasa pengguna. Hal tersebut diperlukan untuk menghindari kesalahan penyajian BMN Semakin tinggi kompetensi SDM, akan sangat menentukan kualitas informasi BMN yang disajikan oleh pemerintah kepada publik. Berdasarkan hal tersebut, hipotesis dalam penelitian ini adalah sebagai berikut :

H1 : Kompetensi sumber daya manusia berpengaruh terhadap penerapan akuntansi berbasis akrual

Putra dan Ariyanto (2015), Kusuma dan Fuad (2013), Rosiana et al. (2016) menggunakan teknologi informasi dalam penerapan akuntansi berbasis akrual. Dalam suatu organisasi dengan penggunaan teknologi informasi yang lebih maju mungkin lebih dapat menerapkan sistem akuntansi yang lebih baik dibandingkan dengan organisasi yang tidak menggunakan teknologi informasi terkini. Termasuk halnya penggunakan teknologi informasi dalam penerapan akutansi pemerintah berbasis akrual. Teknologi informasi seharusnya membantu organisasi dalam keandalan penyajian informasi akuntansi termasuk penyajian BMN, sehingga keberhasilan tersebut tidak lepas dari teknologi informasi yang terdapat dalam suatu instansi/organisasi. Berdasarkan hal tersebut, hipotesis dalam penelitian ini adalah sebagai berikut :

$\mathrm{H} 2$ : Teknologi dan system informasi berpengaruh terhadap penerapan akuntansi berbasis akrual

\section{Metodologi Penelitian Sampel Penelitian}

Penelitian ini merupakan penelitian kuantitif dengan menerapkan survei kuesioner. Kuesioner disebarkan kepada Penguna Barang dan Kuasa Pengguna Barang di 16 Kementerian dan 3 Lembaga Pemerintah, dengan total kuesioner yang disebarkan sebanyak 250 kuesioner. Kuesioner disebarkan kepada Pengguna Barang dan Kuasa Pengguna Barang dengan pertimbangan bahwa mereka adalah pihak yang secara langsung melakukan pengelolaan dan penatausahaan BMN. Pengukuran kuesioner dengan menggunakan skala likert dari 1 sampai 5 dari yang sangat tidak setuju sampai yang sangat setuju. 


\section{Operasionalisasi Variabel}

Variabel dependen dalam penelitian ini adalah penerapan akutansi berbasis akrual. Sedangkan variabel independen dalam penelitian ini adalah komitmen pimpinan organisasi, kompetensi sumber daya manusia, teknologi dan sistem informasi.

Indikator variabel dalam penelitian ini adalah sebagai berikut :

1. Penerapan Akuntansi Pemerintah Berbasis Akrual pada BMN : penyajian laporan penyusutan BMN, penyusutan BMN berupa persediaan, pencatatan BMN berupa tanah, penyusutan BMN pada gedung, bangunan, jembatan, irigasi, jaringan, aset tetap renovasi, alat musik modern, kategori aset kurang dari 12 bulan, kategori aset lebih dari 12 bulan, pengakuan aset yang diperoleh dari APBN dan hibah, beban persediaan dalam laporan operasional, dan beban penyusutan dalam laporan operasional.

2. Kompetensi SDM :

a. pemahaman SDM terhadap penyusunan laporan BMN, pemahaman SDM terhadap penyiapan laporan BMN, pemahaman SDM terhadap dampak penerapan akuntansi berbasis akrual terhadap laporan BMN, pemahaman SDM terhadap tanggapan atas tindak lanjut BPK terhadap temuan BMN, pemahaman SDM terhadap peraturan terkait dengan BMN, pemahaman SDM terhadap pengungkapan BMN dalam Catatan Atas Laporan Keuangan (CALK).

b. Pengetahuan SDM berdasarkan pelatihan dan sosialisasi, pengoperasian aplikasi oleh SDM, kebenaran dan ketepatan penyajian laporan BMN, kemampuan SDM dalam penyusunan CALK.

3. Teknologi Informasi : ketersediaan komputer dalam penyusunan laporan BMN, jaringan internet untuk pengiriman data dan informasi, komputerisasi proses akuntansi BMN, dukungan aplikasi untuk pengolahan data BMN, dan pemeliharan komputer.

\section{Teknik Analisis Data}

Dalam analisis kuantitatif untuk menguji pengaruh variabel independent dan variabel dependen dilakukan dengan regresi linier. Analisis regresi linear dalam penelitian ini menggunakan formula sebagai berikut : $\mathrm{Y} 1=\beta 0+\beta 1 \mathrm{X} 1+\beta 2 \mathrm{X} 2+\varepsilon$

Dimana

$\mathrm{Y} 1=$ penerapan akuntansi berbasis akrual

$\mathrm{X} 1$ = kompetensi sumber daya manusia

$\mathrm{X} 2=$ teknologi dan system informasi

$\varepsilon=$ Error term

\section{Analisis Dan Pembahasan Pengumpulan Data dan Sampel}

Penelitian ini menerapkan survei dengan menggunakan kuesioner dalam menguji penelitian. Kuesioner disebarkan kuasa pengguna dan pengguna barang milik negara sebanyak 250 kuesioner. Jumlah kuesioner yang berhasil dikembalikan dari responden sebanyak 234, sedangkan yang terisi penuh dan dinyatakan valid sebanyak 188 kuesioner. Uji validitas dilakukan terhadap semua item pernyataan dalam kuesioner. Hasilnya semua item pernyataan adalah valid. Selanjutnya, uji realibilitas dilakukan untuk menjamin instrumen yang digunakan merupakan sebuah instrumen yang handal, konsistensi, dan stabil. Hasilnya semua variabel yang dibangun dari kontruk adalah realiable

\section{Statistik Deskriptif}

Statistik deskritptif variabel dependen dan independen adalah sebagai berikut :

$$
\text { Tabel } \quad 4.1
$$

Statistik Deskriptif

\begin{tabular}{|l|l|l|l|l|l|}
\hline Var & $\mathrm{N}$ & Min. & Max. & Mean & SD \\
\hline $\mathrm{Y}$ & 188 & 2.31 & 5.00 & 3.7105 & .52044 \\
\hline $\mathrm{X} 1$ & 188 & 1.30 & 5.00 & 3.9212 & .71820 \\
\hline $\mathrm{X} 2$ & 188 & 1.40 & 5.00 & 4.1915 & .69738 \\
\hline
\end{tabular}

Berdasarkan tabel 4.1. di atas, penerapan akuntansi berbasis akrual pada BMN sudah dilaksanakan dengan cukup baik, karena rata-rata sebesar 3.71. Sementara itu, kompetensi SDM dalam melakukan pengelolaan BMN sudah cukup baik dengan rata-rata sebesar 3,92. Hampir seluruh responden menyatakan memiliki pengetahuan dan keterampilan akuntansi pemerintah 
berbasis akrual untuk pengelolaan BMN. Selanjutnya, teknologi informasi untuk menunjang akuntansi pemerintah berbasis akrual sudah baik, karena memiliki rata-rata sebesar 4,19. Hampir seluruh responden menyatakan bahwa teknologi informasi di kantor responden pengelola BMN telah cukup mendukung pelaksanaan akuntansi berbasis akrual.

\section{Uji Hipotesis}

Setelah melalui uji asumsi klasik dan model penelitian tidak melanggar asumsi klasik, selanjutnya dilakukan uji hipotesis dengan tahap-tahap sebagai berikut

1. Uji Goodness of Fit

Tabel 4.2.

Uji Goodness of Fit

\begin{tabular}{|r|l|l|ll|}
\hline $\begin{array}{l}\text { Mode } \\
1\end{array}$ & $\mathrm{R}$ & R Square & $\begin{array}{l}\text { Adjusted } \\
\text { Square }\end{array}$ & $\mathrm{R}$ \\
\hline 1 & $.345^{\mathrm{a}}$ & .119 & .109 \\
\hline
\end{tabular}

Dari tabel tersebut diketahui bahwa adjusted $\mathrm{R}^{2}$ sebesar 10,9 persen artinya bahwa penerapan akuntansi pemerintah berbasis akrual pada BMN dapat dijelaskan sebesar 10,9 persen oleh kompetensi SDM dan teknologi informasi, sedangkan sisanya dijelaskan oleh variabel diluar model penelitian.

2. Uji F (uji kelayakan model) :

Tabel 4.3.

\begin{tabular}{|l|l|l|l|l|l|}
\hline \multicolumn{1}{|c|}{ Uji F } \\
\hline Model & SS & df & $\begin{array}{l}\text { Mean } \\
\text { Square }\end{array}$ & F & Sig. \\
\hline $\begin{array}{l}\text { Regressi } \\
\text { on }\end{array}$ & $\begin{array}{l}1020.84 \\
6\end{array}$ & 2 & 510.423 & 12.49 & $.000^{\mathrm{b}}$ \\
\hline Residual & $\begin{array}{l}7558.87 \\
2\end{array}$ & 185 & 40.859 & & \\
\hline Total & $\begin{array}{l}8579.71 \\
8\end{array}$ & 187 & & & \\
\hline
\end{tabular}

Dari tabel tersebut, dapat diketahui bahwa Sig sebesar 0.000 (kurang dari 0.05) bahwa model penelitiandapat digunakan. Dengan demikian, dapat disimpulkan bahwa secara bersama-sama kompetensi SDM dan teknologi informasi berpengaruh terhadap penerapan akuntansi pemerintah berbasis akrual pada BMN.
3. Uji T (Uji Parsial)

Tabel 4.3

Uji T

\begin{tabular}{|c|r|r|r|l|}
\hline & \multicolumn{1}{|c|}{ Coeff } & \multicolumn{1}{c|}{$\mathrm{t}$} & Sig. & Keterangan \\
\hline Cons & 32.940 & 10.252 & .000 \\
\hline X1 & .252 & 3.480 & .001 Signifikan \\
\hline X2 & .257 & 1.725 & .086 & $\begin{array}{l}\text { Tidak } \\
\text { Signiikan }\end{array}$ \\
\hline
\end{tabular}

Dari tabel di atas, dapat diketahui bahwa kompetensi berpengaruh signifikan positif terhadap penerapan akuntansi pemerintah berbasis akrual pada BMN karena sig sebesar 0.01 (kurang dari 0.05) dan koefisien variabel dalam positif (0.252). Sementara itu, teknologi informasi tidak berpengaruh terhadap penerapan akuntansi pemerintah berbasis akrual pada BMN karena sig sebesar 0.086 (lebih dari 0.05).

\section{Pembahasan}

1. Pengaruh Kompetensi SDM terhadap penerapan akuntansi pemerintah berbasis akrual pada BMN Dari hasil pengujian hipotesis diketahui bahwa kompetensi SDM berpengaruh positif terhadap penerapan akuntansi pemerintah berbasis akrual pada BMN. Semakin tinggi kompotensi SDM, semakin berhasil penerapan akutansi pemerintah berbasis akrual pada BMN. Pemerintah telah berhasil dalam menempatkan pegawai pengelola BMN yang memiliki pengetahuan yang memadai atas akuntansi berbasis akrual khususnya pada pengelolaan BMN. Selain itu, keterampilan SDM pengelolaan BMN diperlukan dalam penyusunan laporan BMN yang andal dalam penyajian informasikepada publik selaku pemangku kepentingan. Peningkatan kemampuan berkelanjutan melalui pelatihan sangat diperlukan untuk menunjang keberhasilan penerapan akuntansi berbasis akrual dalam pengelolaan BMN. Kompetensi SDM memegang peranan penting dalam penerapan standar akuntansi baru yang semula cash toward accrual menjadi fully accrual. Hal yang sama berlaku terhadap persiapan akuntansi berbasis akrual, kualitas SDM sangat mempengaruhi kesuksesan adanya perubahan standar akuntansi sebagaimana penelitian yang 
dilakukan oleh Putra dan Ariyanto (2015), Azman (2015)

2. Pengaruh Teknologi Informasi terhadap penerapan akuntansi pemerintah berbasis akrual pada BMN Dari hasil pengujian hipotesis diketahui bahwa teknologi informasi tidak berpengaruh terhadap penerapan akuntansi pemerintah berbasis akrual pada BMN. Teknologi informasi yang baik seperti komputer yang memadai, koneksi internet yang baik, komputerisasi BMN, adanya perangkat lunak yang mendukung dan pemeliharaan komputer yang berada dikantor pengelolaan BMN tidak menjamin keberhasilan penerapan akuntansi pemerintah berbasis akrual pada BMN. Hal tersebut berlaku sebaliknya dengan kondisi teknologi informasi yang kurang baik di kantor pengelola BMN. Penyediaan penyediaan perangkat keras komputer yang mendukung pelaksanaan akuntansi pemerintah berbasis akrual tidak cukup mendukung keberhasilan penerapan akuntansi pemerintah akrual pada pengelolaan BMN. Kondisi demikian perlu menjadi perhatian bagi Pemerintah mengingat investasi di bidang teknologi informasi khususnya perangkat keras dapat menjadi sia-sia tanpa memperoleh manfaat dalam pelaksanaan akuntansi berbasis akrual untuk pengelolaan BMN. Dari hasil saran respondent yang masuk, sebagian besar respondent menyatakan kebutuhan aplikasi penatausahaan BMN yang up to date, handal, siap pakai dan tepat waktu. Hal ini menunjukkan bahwa keberhasilan penerapan akuntansi Pemerintah berbasis akrual perlu didukung dengan aplikasi penatausahaan BMN yang handal. Kebutuhan ini perlu direspons oleh Pemerintah.

Sebagian respondent juga menyatakan perlunya pelatihan terkait penyusunan pelaporan BMN dan aplikasi pendukungnya secara berkesinambungan.

\section{Kesimpulan, Keterbatasan dan Penelitian Selanjutnya \\ Kesimpulan \\ Kesimpulan dalam penelitian ini adalah sebagai berikut :}

1. Kompetensi SDM berpengaruhterhadap penerapan akuntansi pemerintah berbasis akural pada BMN.

2. Teknologi informasi tidak berpengaruh terhadap penerapan akuntansi pemerintah berbasis akrual pada BMN.

\section{Keterbatasan Penelitian}

1. Penelitian ini hanya menggunakan sampel yang tersebar pada beberapa kementerian/lembaga pemerintah pusat.

2. Waktu yang digunakan dalam penelitian ini selama 5 minggu

\section{Implikasi}

1. Implikasi Praktis

Penelitian ini diharapkan dapat menjadi masukan bagi Pemerintah dalam penerapan akuntansi berbasis akrual khususnya dalam pengelolaan BMN. Kompetensi SDM yang baik diperlukan dalam keberhasilan penerapan akuntansi akrual. Penempatan pegawai yang memiliki kompetensi harus menjadi perhatian bagi Pemerintah dan perlunya peningkatan kemampuan berkelanjutan bagi SDM pengelola SDM. Pemerintah perlu mempunya terobosan terhadap teknologi informasi agar dapat menunjang keberhasilan penerapan akuntansi berbasis akrual pada BMN

2. Implikasi Akademis

a. Penelitan selanjutnya dapat mengelompokkan responden per kementerian/lembaga dan menggunakan sampel yang lebih besar.

b. Objek pengelolaan barang milik negara dapat menggunakan objek pemerintah daerah.

\section{Daftar Rujukan}

Athukorala, S. L. (2003). Accrual Budgeting and Accounting in Government and its Relevance for Developing Member. Asian Development Bank.

Azman, T. (2015). Analisis Komitemen Organisasi, Kesiapan Sumberdaya Manusia, Infrastruktur serta Sistem Informasi dalam Menerapkan Standar Akuntansi Pemerintah Berbasis Akrual (Studi pada Pemerintah Kabupaten Kepulauan Meranti). Jurnal SOROT, Lembaga Penelitian 
Dan Pengabdian Masyarakat Universitas Riau, 10(April), 131-142.

Eisenhardt, K. M. (1989). Agency Theory: Assessment and Review. Academy of Management Review, 4(1). Retrieved from https://www.jstor.org/stable/258191

Gaffikin, M. (2007). Accounting Research and Theory: The age of neo- empiricism. Australasian Accounting Business and Finance Journal, 1(1).

Hu, F., Percy, M., \& Yao, D. (2015). Asset revaluations and earnings management: Evidence from Australian companies. Corporate Ownership and Control, 13(1CONT11), 1287-1296.

Jensen, M. C., \& Meckling, W. H. (1976). Theory of the firm: Managerial behavior, agency costs and ownership structure. Journal of Financial Economics, 3(4), 305-360. https://doi.org/10.1016/0304-405X(76)90026-X

Khan, A., \& Mayes, S. (2009). Transition to Accrual Accounting. International Monetary Fund.

Kusuma, M. I. Y., \& Fuad, F. (2013). Analisis FaktorFaktor yang Memengaruhi Tingkat Penerapan Akuntansi Akrual pada Pemerintah. Diponegoro Journal of Accounting, 15(1), 67-79.

Oscar, O. B., \& Gustafsson. (2014). Communication within an Agency Relationship: A study on Bostadsbolaget and the "Deferred Revenues." University of Gothenburg - School of Business, Economics and Law.

Putra, I. W. G. Y., \& Ariyanto, D. (2015). Faktor-Faktor yang Mempengaruhi Penerapan Standar Akuntansi Pemerintah Berbasis Akrual. EJurnal Akuntansi Universitas Udayana, 14-32.

Rosiana, E., Made, A., \& Yogivaria, D. W. (2016). Pengaruh Kualitas SDM dan Teknologi Informasi terhadap Penerapan SAP Berbasis Akrual PP No 71 Tahun 2010 (Studi Kasus pada SKPD-SKPD Pemerintah Kota Malang). 